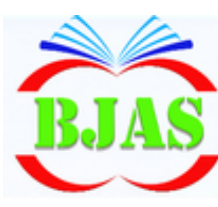

ISSN $1814-5868$
Available online at http://bjas.bajas.edu.iq

https://doi.org/10.37077/25200860.2020.33.1.16

College of Agriculture, University of Basrah

Basrah J. Agric. Sci., 33(1): 213-220, 2020
Basrah Journal

of Agricultural

Sciences

E-ISSN: 2520-0860

\title{
Study some of Morphological and Physiological Traits of Kurrajong Brachychiton populneus (Schott \& Endl.) Seedlings Planted under Water Stress Conditions
}

\author{
Shaima A. Karim, Sirwa A. Qadir \& Halmat A. Sabr* \\ Department of Forestry, College of Agricultural Engineering Sciences, Salahaddin \\ .University-Erbil, Iraq \\ *Corresponding author-mail: halmat.sabr@su.edu.krd
}

Received 20 August 2019; Accepted 4 December 2019; Available online 27 June 2020

\begin{abstract}
In this study, Brachychiton populneus seedlings were subjected to drought stress for 90 Days and physiological and morphological characters analyzed to determine their response to water deficit. The growth characters including, height and diameter of shoots, the dry weight of shoots and roots as well as photosynthetic pigment and the leaves content of relative water content were measured to evaluate the effects of drought in the physiological growth of plant. The lowest means; $59 \mathrm{~cm}$ and $8 \mathrm{~mm}$ of shoot height and diameter respectively were recorded at $30 \%$ of water holding capacity of soil (WHC). Drought treated seedlings at both $60 \%$ and $30 \%$ WHC had lower dry weight of shoots; 9.54 and $8.24 \mathrm{~g}$ plant $^{-1}$ respectively compared to the control. Consequently, the increase of drought conditions led to enhancement the growth of roots and roots to shoots ratio. The highest increase in the dry weight of roots and roots to shoots ratio were $25.96 \mathrm{~g} \mathrm{plant}^{-1}$ and 3.19 recorded under severe drought stress condition. Lowest amount of chlorophyll a; $2.94 \mathrm{mg} \mathrm{g}^{-1} \mathrm{~F}$ W recorded under $30 \%$ SWHC. It is found also the total content of chlorophyll in the leaves decreased significantly; 5.86 and $7.88 \mathrm{mg} \mathrm{g}^{-1} \mathrm{~F} \mathrm{~W}$ under both levels. While the highest ratio of chlorophyll a: b was 1.59 recorded at $60 \%$ SWHC. However, the lowest leave relative water content LRWC\%; 86\% was recorded under 30\% SWHC. These findings may explain the characters of the early growth and physiological responses of, Brachychiton populneus to dehydration and facilitate the selection of drought-resistant tree families.
\end{abstract}

Keywords: Brachychiton populneus, Height, Chlorophyll, Carotenoids, LRWC\%.

\section{Introduction}

Drought is the major abiotic stresses determining a global vegetation distribution in the forestry and agricultural sector. The shifts in rainfall patterns in arid and semi-arid regions and increase temperatures associated with climate change are likely to cause widespread forest decline in regions where droughts are predicted to increase in duration and severity (Choat et al., 2012). Brachychiton populneus is predominantly belongs to an Australian genus of the family Sterculiaceae. It is considered a native to 
eastern Australia which has a widespread distribution, and has great value in cultivation (Guymer, 1988). It is easy to propagate and possess many interesting features. It is modest size evergreen, broad domed tree $10-20 \mathrm{~m}$ in height, 12 to $15 \mathrm{~m}$ in crown diameter generally with a stout trunk. In addition, it has an important role in contemporary urban landscapes. Historically, the fiber of the bark was used by Aborigines for making cordage and nets, while early explorers and settlers roasted and ground the seeds to make a pleasant beverage (Buist et al., 2000). Under water deficit growth and development of woody species growth characters including seedling height, stem diameter, plant biomass and leaf area are reduced under drought stress. As well as the leaf's metabolism changes lead to change in water potential, gas exchange, chlorophyll fluorescence, organic solute contents and photosynthetic pigment (Frosi et al., 2017). Some species decrease their photosynthetic pigments and accumulate organic solutes without showing a faster recovery of the photosynthetic activity, while other species show the opposite action (Souza et al., 2010).

The hydraulic status of plants under water deficit condition has more attention recently. Under water deficit, the ability of plants to supply water to leaves for photosynthetic and gas exchanges is reduced as well as a few water movement through the xylem under tension during transpiration that can be ultimately result in desiccation and mortality. Therefore, high transpiration rate during the drought season led to increases the risk of xylem cavitation (Steudle, 2001).

B. populneus seedlings were brought to the Kurdistan region during the years 2006-2007 and used as ornamental trees widely in the city of Erbil. It has been identified at the herbarium center in Department of Biology, College of Education, University of Salahaddin. As the afforestation projects took large allowance of the government's interest; it's noteworthy to study the growth performance of B. populneus seedlings under moisture tension in Kurdistan region, Iraq.

\section{Materials \& Methods}

This study was conducted at a lath house at College of Agriculture, Erbil. Local Brachychiton populneus seedlings were subjected to two levels of water holding capacity for 90 days. The water holding capacity of the soil was determined by saturating the soil in pots, covering the tops with aluminum foil. Regular daily weighing after 24, 48 and 72 hours until a constant weight obtained. On this base $1500 \mathrm{~mL}, 1000$ $\mathrm{mL}$ and $500 \mathrm{~mL}$ water added respectively as; $90 \%, 60 \%$ and $30 \%$ soil water holding capacity (SWHC \%) levels (Qadir et al., 2016).

\section{Experimental parameters}

\section{Morphological Characteristics:}

Seedling height $(\mathrm{cm})$ and seedling diameter $(\mathrm{mm})$.

\section{Biomass characters}

Biomass characters were measured after separating the seedling to shoot and root and dried in an oven at $72^{\circ} \mathrm{C}$ until the constant weight obtained (Paliwal et al., 1998).

The shoot dry weight $\mathrm{g}$ plant $^{-1}$, root dry weight $g$ plant ${ }^{-1}$, seedling dry weight g plant $^{-1}$ and root to shoot ratio was calculated.

\section{Photosynthetic pigments}

Pigments extracted in $95 \%$ ethanol and spectrophotometric determination absorbance taken at 663.2, 646.8 and $470 \mathrm{~nm}$. Chlorophylls and carotenoid contents were 
calculated using the following formulas as described by Sumanta et al. (2014).

Chlorophyll a =13.36A664 - 5.19 A649

Chlorophyll b=27.43A649 - 8.12 A664

Total chlorophyll $=$ Chlorophyll $\mathrm{a}+$ Chlorophyll $\mathrm{b}$

Carotenoids $=(1000 \mathrm{~A} 470-2.13 \mathrm{Ca}--97.63 \mathrm{Cb}) / 209$

\section{Leaf relative water content (LRWC)}

Leaf relative water content of seedlings was measured by sampling two similar fully expanded leaves per plot. Leaf samples were sealed in plastic, placed above ice in cooler and transported to the lab to obtain fresh weight. Then leaves floated on water for 24 hours to saturate and obtain the turgid weight. Turgid leaves dried at $70^{\circ} \mathrm{C}$ until constant weight was reached (Schon-feld et al., 1990). LRWC were calculated according to the formula:

$\mathrm{RWC}=[(\mathrm{FW}-\mathrm{DW}) /(\mathrm{TG}-\mathrm{DW})] \times 100$

FW =Sample fresh weight

$\mathrm{TW}=$ Sample turgid weight

DW $=$ Sample dry weight

\section{Experimental design and data analysing}

The Complete Randomized based to design (CRD) the study in the nature of three SWHC\% levels repeated four times. The mean values were compared using Duncan's multiple range test DMRT IBM SPSS Statistics version 25 was used to analyze the data.

\section{Results \& Discussion}

To evaluate the growth of $B$. populneus seedlings subjected to drought stress, shoot heights and stem diameter were measured on the last $\left(90^{\text {th }}\right)$ day of drought treatment (Fig. 1). There were significant decreases recorded in the shoot height and stem diameter. The lowest means; $59 \mathrm{~cm}$ and $8 \mathrm{~mm}$ of shoot height and stem diameter were recorded in drought-treated $30 \% \mathrm{WHC}$ of the soil as compared to their control treatment $90 \%$ SWHC. That might be belongs to reduction in cell division and enlargement (Frosi et al., 2017). According to Lecoeur et al. (1995) during growing plants for a period of time in soils with low water potential, smaller leaves

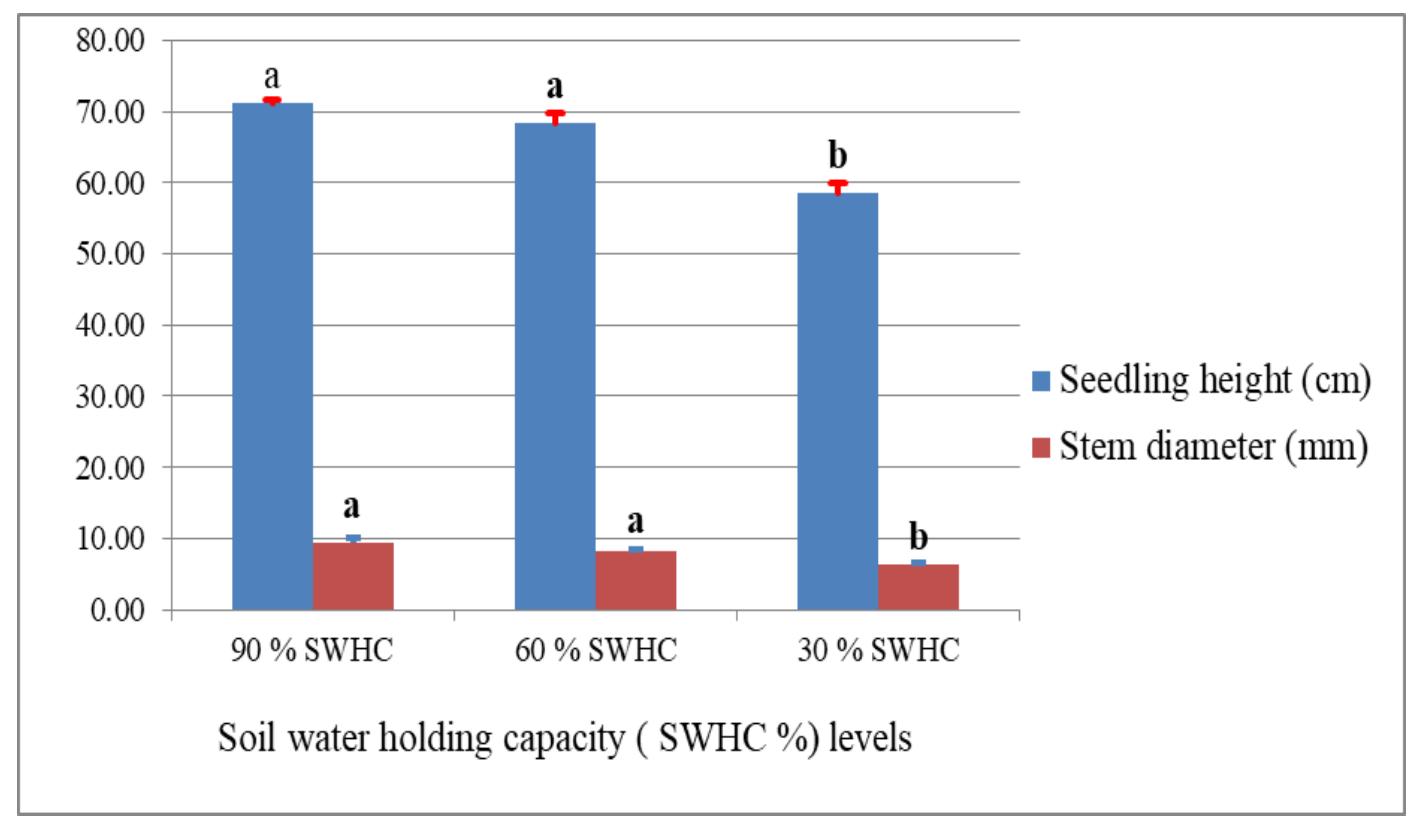

Fig. (1): Seedling height (cm) and stem diameter (mm) of B. populneus under different soil water holding capacity levels. 
with fewer cells are produced, these explanation recommend that reduced cell formation during water stress may reduce final leaf size. Similar results were observed in Populus $\times$ euramericana clones (Marron et al., 2002) and Celtis caucasica seedlings (Tabatabaei et al., 2014). Drought treated seedlings at both 60 and 30\% WHC had lower shoot dry weights; 9.54 and $8.24 \mathrm{~g} \mathrm{plant}^{-1}$ than their counterparts control (90\% SWHC); $17.50 \mathrm{~g}$ plant $^{-1}$ (Table 1), as previously described by Lim et al. (2017).

The dry weight is closely correlated with the seedling collar diameter. Both the dry weight and stem collar diameter significantly influence. Seedling survival and growth (Ritchie, 1984). In dry conditions the plant respond through reduction in leaf area as soil water becomes limiting is achieved through reduction in leaf size, leaf rolling or leaf shedding, thus reducing the transpiring leaf surface, but with significant negative impact on carbon gain and overall plant productivity (Jones, 1992). Leaf fall can be caused by water shortages and reduce the level of transpiration way to resist is dry. This increase in plant adaptation to drought; ethylene produced by stress, such as a secondary messenger for reactions to plant operation (Jalili Marandi, 2010). Consequently, increasing drought conditions may result in enhanced root growth and root to shoot ratio (Noguchi et al., 2007). The highest increase in root dry weight and root: shoot ratio $25.96 \mathrm{~g} \mathrm{plant}^{-1}$ and 3.19 were recorded under severe drought stress condition. This is also recorded in previous studies by Rötzer et al. (2017). Thus, water uptake of trees in periods with low water availability can be ensured by carbon allocation to the roots. Because of roots have direct contact with soil and absorb water from the soil. Therefore, roots regarded as good scale for response to drought stress (Leuschner et al., 2001).

Table (1): Biomass characters of B. populneus seedlings under different soil water holding capacity levels (SWHC \%).

\begin{tabular}{rcccc}
\hline \multirow{2}{*}{ Biomass characters } & \multicolumn{4}{c}{ SWHC \% levels } \\
\cline { 2 - 5 } & $90 \%$ SWHC & $60 \%$ SWHC & $30 \%$ SWHC & Mean \\
\hline Shoot dry weight $\left(\mathrm{g} \mathrm{plant}^{-1}\right)$ & $17.50 \mathrm{a} \pm 1.67$ & $9.54 \mathrm{~b} \pm 0.24$ & $8.24 \mathrm{~b} \pm 0.49$ & $11.78 \pm 1.54$ \\
\hline Root dry weight $\left(\mathrm{g} \mathrm{plant}^{-1}\right)$ & $19.40 \mathrm{~b} \pm 1.12$ & $22.66 \mathrm{ab} \pm 1.40$ & $25.96 \mathrm{a} \pm 1.13$ & $22.67 \pm 1.13$ \\
\hline Seedling dry weight $(\mathrm{g}$ \\
plant
\end{tabular}


The leaf chlorophyll content is directly correlated to the photosynthetic activity under drought stress condition. The chlorophyll content in drought-treated $B$. populneus seedlings significantly differs from that of the controls (Table 2). Lowest amount of chlorophyll a; $2.94 \mathrm{mg} . \mathrm{g}^{-1} \mathrm{~F}$ W recorded under $30 \%$ SWHC. Furthermore, the amount of chlorophyll; 3.05 and $2.91 \mathrm{mg} \mathrm{g}^{-1} \mathrm{~F}$ W under moderate and severe drought stress levels. As well as total chlorophyll content decreased

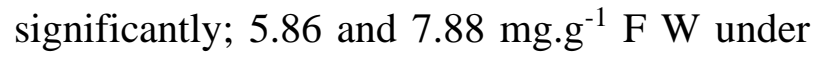
the same levels as compared to the control seedlings. While the highest ratio of chlorophyll a: b was 1.59 recorded at $60 \%$ SWHC. Similar responses in photosynthetic pigments were present in Olea europaea (Guerfel et al., 2009) as well as Frosi et al. (2017) recorded the same results. Avoiding severe damages strategy might include decrease in photosynthetic pigment could directly affect the photosynthetic machinery, as well as lower $\mathrm{CO}_{2}$ concentrations inside the chloroplast can be caused by stomatal closure may have an inhibitory effect on photosynthetic machinery (de Lima et al., 2015).

Relative water content is the main factor which caused growth reduction in response. Decrease in RWC in plants under drought stress may depend on plant vigor reduction (Alexieva et al., 2001).

A significant decrease observed in leaves water content of Brachychton sp. under 30\% SWHC as compared to control (Fig. 2). In which the lowest LRWC\%; 86\% was recorded. While moderate treatments did not differ under water deficit, as previously reported by Souza et al. (2010).

Cell membrane subjects to an increase in its permeability and decrease in stability during subjecting seedlings under drought stress (Blokhina et al., 2003). Due to damaged cleavage in the membrane and sedimentation of cytoplasm content probably, in these conditions, ability to osmotic adjustment is reduced (Blackman et al., 1995).

Table (2): Photosynthetic pigments in B. populneus seedling leaves under different soil water holding capacity levels (SWHC \%).

\begin{tabular}{ccccc}
\hline \multirow{2}{*}{ Photosynthetic pigments } & \multicolumn{4}{c}{ SWHC \% levels } \\
\cline { 2 - 5 } & $90 \%$ SWHC & $60 \%$ SWHC & $30 \%$ SWHC & Mean \\
\hline Chlorophyll a $\left(\mathrm{mg} \mathrm{g}^{-1} \mathrm{~F} \mathrm{~W}\right)$ & $5.036 \mathrm{a} \pm 0.13$ & $4.83 \mathrm{a} \pm 0.03$ & $2.94 \mathrm{~b} \pm 0.16$ & $4.27 \pm 0.34$ \\
\hline Chlorophyll $\mathrm{b}\left(\mathrm{mg} \mathrm{g}^{-1} \mathrm{~F} \mathrm{~W}\right)$ & $3.97 \mathrm{a} \pm 0.08$ & $3.05 \mathrm{~b} \pm 0.16$ & $2.91 \mathrm{~b} \pm 0.13$ & $3.31 \pm 0.18$ \\
\hline Total chlorophyll $\left(\mathrm{mg} \mathrm{g}^{-1} \mathrm{~F} \mathrm{~W}\right)$ & $9.01 \mathrm{a} \pm 0.18$ & $7.88 \mathrm{~b} \pm 0.17$ & $5.86 \mathrm{c} \pm 0.11$ & $7.58 \pm 0.47$ \\
\hline Carotenoids $\left(\mathrm{mg} \mathrm{g}^{-1} \mathrm{~F} \mathrm{~W}\right)$ & $0.54 \mathrm{a} \pm 0.02$ & $0.55 \mathrm{a} \pm 0.01$ & $0.39 \mathrm{a} \pm 0.06$ & $0.49 \pm 0.03$ \\
\hline Chlorophyll a: $\mathrm{b}$ & $1.27 \mathrm{ab} \pm 0.03$ & $1.59 \mathrm{~b} \pm 0.08$ & $1.02 \mathrm{a} \pm 0.10$ & $1.29 \pm 0.10$ \\
\hline Chlorophyll: carotenoids & $16.83 \mathrm{a} \pm 0.47$ & $14.22 \mathrm{a} \pm 0.53$ & $15.69 \mathrm{a} \pm 2.67$ & $15.58 \pm 0.88$
\end{tabular}




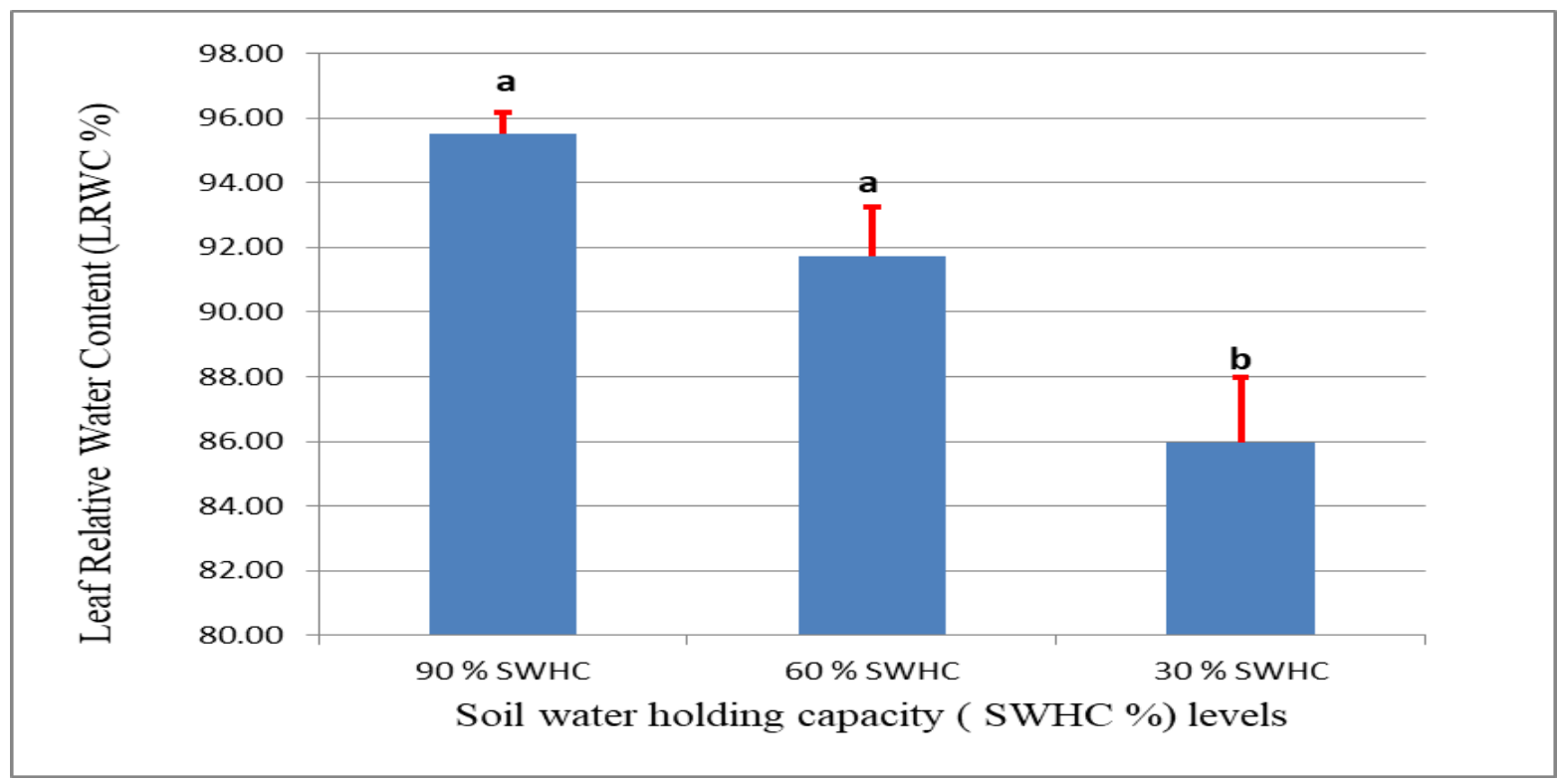

Fig. (2): Leaf relative water content (LRWC \%) in B. populneus leaves under different soil water holding capacity levels.

\section{Conclusion}

The study results may assist in the understanding of the initial growth and physiological responses of $B$. populneus under drought stress and facilitate the selection of drought-resistant tree families. It is resistant plants to drought which is suitable for sowing in dry and hot areas. To increase the green places in the city by planting streets, parks, playgrounds and backyards are lined with trees that create a peaceful, aesthetically pleasing environment.

\section{Acknowledgements}

The authors greatly acknowledge the staff of Department of Forestry, College of Agriculture Engineering Sciences, Salahaddin University for their valuable help in the preparation of this paper. We thank Mr. Hawar A. Sadiq a manager from Grdrasha Research Centre who helped us for conducting an experiment.

\section{Conflicts of interest}

The authors-declare-that they-have-noconflict of interests.

\section{References}

Alexieva, V.; Sergiev, I.; Mapelli, S \& Karanov, E. (2001). The effect of drought and ultraviolet radiation on growth and stress markers in pea and wheat. Plant Cell Environ., 24(12): 1337-1344. https://doi.org/10.1046/j.13653040.2001.00778.x

Blackman, S.A.; Obendorf, R.L. \& Leopold, A.C. (1995). Desiccation tolerance in developing soybean seeds: the role of stress proteins. Physiol. Plant, 93(4): 630638. https://doi.org/10.1111/j.13993054.1995.tb05110.x

Blokhina, O.; Virolainen, E. \& Fagerstedt, K.V. (2003). Antioxidants, oxidative damage and oxygen deprivation stress: A review Ann. Bot., 91(2): 179-194. https://doi.org/10.1093/aob/mcf118 
Buist, M.; Yates, C.J. \& Ladd, P.G. (2000). Ecological characteristics of Brachychiton populenus (Sterculiaceae) (Kurrajong) in relation to the invasion of urban bushland in south western Australia. Austral Ecol., 25(5): 487$496 . \quad$ https://doi.org/10.1046/j.14429993.2000.01082.x

Choat, B.; Jansen, S.; Brodribb, T.J.; Cochard, H; Delzon, S; Bhaskar, R. \& Jacobsen, A.L. (2012). Global convergence in the vulnerability of forests to drought. Nature, 491: 752-755. https://doi.org/10.1038/nature11688

de Lima, R.S.N.; de Assis, F.A.M.M.; Martins, A.O.; de Deus, B.C.D.S.; Ferraz, T.M.; de Assis Gomes, M.D.M. \& Campostrini, E. (2015). Partial root zone drying (PRD) and regulated deficit irrigation (RDI) effects on stomatal conductance, growth, photosynthetic capacity, and water-use efficiency of papaya. Sci. Hortic., 183: 13-22. https://doi.org/10.1016/j.scienta.2014.12.0 05

Frosi, G.; Harand, W.; Oliveira, M.T.D.; Pereira, S.; Cabral, S.P.; Montenegro, A.A.D.A. \& Santos, M.G. (2017). Different physiological responses under drought stress result in different recovery abilities of two tropical woody evergreen species. Acta Bot. Bras., 31(2): 153-160. https://doi.org/10.1590/0102$33062016 \mathrm{abb} 0375$

Guerfel, M.; Baccouri, O.; Boujnah, D.; Chaïbi, W. \& Zarrouk, M. (2009). Impacts of water stress on gas exchange, water relations, chlorophyll content and leaf structure in the two main Tunisian olive (Olea europaea L.) cultivars. Sci. Hortic., 119(3):

257-263. https://doi.org/10.1016/j.scienta.2008.08.0 06

Guymer, G.P. (1988). A taxonomic revision of Brachychiton (Sterculiaceae). Aust. Syst. $\quad$ Bot., 1(3): 199-323. https://doi.org/10.1071/SB9880199

Leuschner, C.; Backes, K.; Hertel, D.; Schipka, F.; Schmitt, U.; Terborg, O.; \& Runge, M. (2001). Drought responses at leaf stem and fine root levels of competitive Fagus sylvatica L. and Quercus petraea (Matt.) Liebl. trees in dry and wet years. For. Ecol. Manag., 149(13): 33-46. https://doi.org/10.1016/S03781127(00)00543-0

Lecoeur, J.; Wery, J.; Turc, O. \& Tardieu, F. (1995). Expansion of pea leaves subjected to short water deficit: cell number and cell size are sensitive to stress at different periods of leaf development. J. Exp. Bot., 46:

1093-1101.

https://doi.org/10.1093/jxb/46.9.1093

Lim, H.; Kang, J.W.; Lee, S.; Lee, H. \& Lee, W.Y. (2017). Growth and physiological responses of Quercus acutissima seedling under drought stress. Plant Breed. Biol., 5(4): 363-370. https://doi.org/10.9787/PBB.2017.5.4.363

Marron, N.; Delay, D.; Petit, J. M.; Dreyer, E.; Kahlem, G.; Delmotte, F.M. \& Brignolas, F. (2002). Physiological traits of two Populus $\times$ euramericana clones, Luisa Avanzo and Dorskamp, during a water stress and re-watering cycle. Tree Physiol., 22(12): 849-858. https://doi.org/10.1093/treephys/22.12.849

Noguchi, K.; Konôpka, B.; Satomura, T.; Kaneko, S. \& Takahashi, M. (2007). Biomass and production of fine roots in Japanese forests. J. For. Res., 12(2): 8395. 
Paliwal, K.; Karunaichamy, K.S.T.K. \& Ananthavalli, M. (1998). Effect of sewage water irrigation on growth performance, biomass and nutrient accumulation in Hardwickia binata under nursery conditions. Bioresour. Technol., 66(2): 105-111. https://doi.org/10.1016/S09608524(98)00044-3

Qadir, S.A.; Khursheed, M.Q. \& Huyop, F.Z. (2016). Effect of drought stress on morphology, growth and yield of six bread wheat (Triticum aestivum L.) cultivars. ZANCO J. Pure Appl. Sci., 28(3): 37-48. https://doi.org/10.21271/zjpas.v28i3.906

Ritchie, G.A. (1984). Assessing seedling quality. 243-259. In Duryea, M.L. (Ed.). Forestry Nursery Manual: Production of Bareroot Seedlings. Springer, Dordrecht: 365pp.

Rötzer, T.; Biber, P.; Moser, A.; Schäfer, C. \& Pretzsch, H. (2017). Stem and root diameter growth of European beech and Norway spruce under extreme drought. For. Ecol. Manag., 406: 184-195. https://doi.org/10.1016/j.foreco.2017.09.0 70

Souza, B.D., Meiado, M.V., Rodrigues, B.M. \& Santos, M.G. (2010). Water relations and chlorophyll fluorescence responses of two leguminous trees from the Caatinga to different watering regimes. Acta Physiol Plant., 32(2): 235-244.

Sumanta, N.; Haque, C.I.; Nishika, J. \& Suprakash, R. (2014). Spectrophotometric analysis of chlorophylls and carotenoids from commonly grown fern species by using various extracting solvents. Res. J. Chem. Sci., 4(9): 63-69.

Tabatabaei, S.A.; Jalilvand, H. \& Ahani, H. (2014). Drought stress response in caucasian hackberry: Growth and morphology. JBES, 5(3): 158-169.

دراسة بعض الصفات المورفولوجية والفسلجية لشتلات Brachychiton populneus (Schott \& Endl.) Kurrajong شيماء عبدالخالق كريم و سروه انور قادر وحلمت ابوبكر صابر قسم الغابات، كلية علوم الهندسة الزر اعية، جامعة صلاح الدين، اربيل، العر اق لقوره المستخلص: تعرضت شتلات Brachychiton populneus في الدراسة الحالية للجفاف لمدة 90 يومًا وتم

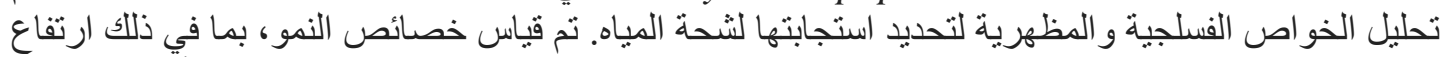

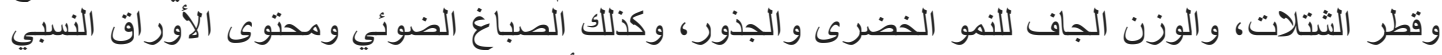

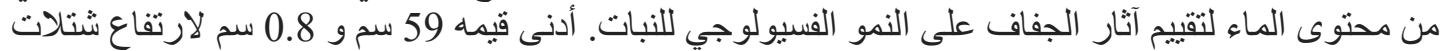

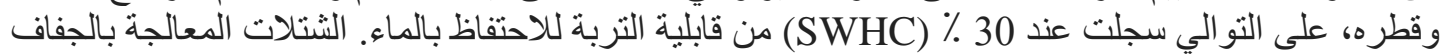

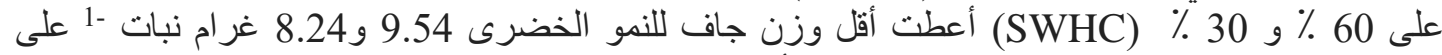

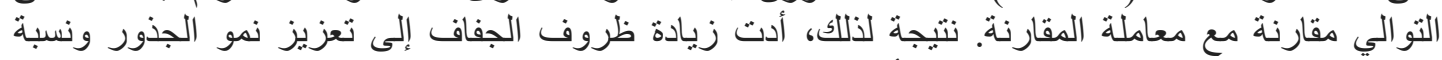

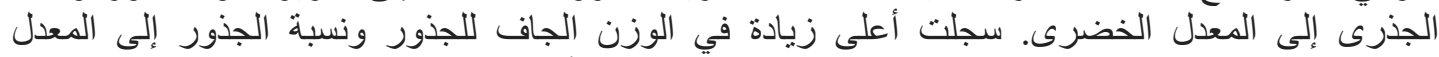

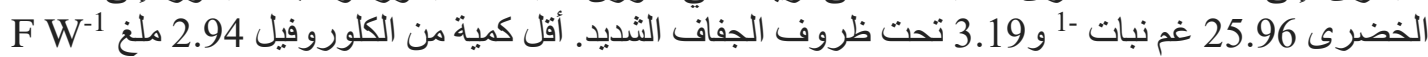

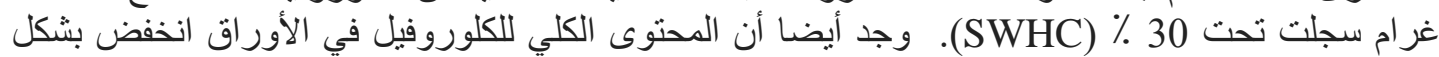

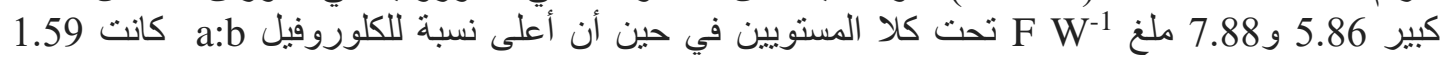

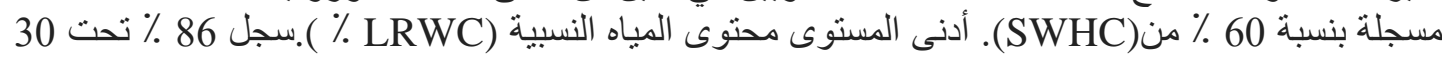

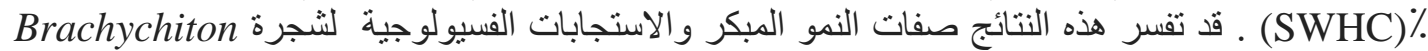
populneus 